\title{
The Effect of Number of Visitors, Tourist Destinations, Hotel Room Tax and Accommodations on Original Local Government Revenue: Case Study West Sumatra Province, Indonesia
}

\author{
Lusiana $^{1}$, Mondra Neldi ${ }^{1}$, Sigit Sanjaya ${ }^{1} \&$ Zefriyenni $^{1}$ \\ ${ }^{1}$ Universitas Putra Indonesia YPTK, Indonesia \\ Correspondance: Sigit Sanjaya, Faculty of Economics and Business, Universitas Putra Indonesia YPTK Padang, \\ Indonesia. Tel: 62-852-6384-9667. E-mail: SigitSanjaya@upiyptk.ac.id
}

Received: October 30, 2020

Accepted: December 28, 2020

Online Published: January 20, 2021

doi:10.5430/ijfr.v12n3p230

URL: https://doi.org/10.5430/ijfr.v12n3p230

This paper has been previously presented in the International Conference of Business, Accounting and Economics (ICBAE) 2021 Purwokerto, Indonesia.

\begin{abstract}
This research aims to discover 1) The effect of number of domestic visitors on Original Local Government Revenue (OLGR) 2) The effect of number of foreign visitors on OLGR 3) The effect of number of tourist destinations on OLGR 4) The effect of restaurant tax on OLGR 5) The effect of hotel room tax on OLGR 6) Number of accommodations as a moderating variable for relationship hotel room tax and OLGR. The study population consisted of 12 regencies and 7 municipalities. The sampling technique uses purposive sampling. The selected sample is considered the most appropriate to represent tourism according to Tourism Office of West Sumatra Province. The selected sample is 3 municipalities and 2 regencies. Data source obtain from Central Bureau of Statistics (BPS) West Sumatra Province. Data analysis consisted of statistical descriptive analysis, model estimation test, classical assumption test, coefficient of determination test, F-test and t-test. The results show 1) The number of domestic visitors has a positive and significant effect on OLGR 2) The number of foreign visitors has a positive and significant effect on OLGR 3) The number of tourist destinations has a positive and significant effect on OLGR 4) Restaurant tax has a positive and significant effect on OLGR 5) Hotel room tax has a positive and significant effect on OLGR 6) Number of accommodations show evidence as a moderating variable for relationship hotel room tax and OLGR.
\end{abstract}

Keywords: number of visitors, tourist destinations, hotel room tax, number of accommodations, original local government revenue

\section{Introduction}

Regional autonomy policy can have a positive effect on the regions in terms of regional sovereignty to regulate their domains. When compared to a centralized system, this policy is considered to be superior because the regions are the main actors in development and are not side players. Since the implementation of regional autonomy, this policy had a significant effect on the regions to maximize the existing potential due to the implementation of decentralization. Decentralization policies also have an impact on a country's economic growth and reduce poverty (Feltenstein \& Iwata, 2005); (Condro et al., 2019)

Local governments need to encourage community-based economic sectors or local revenue optimization. The central government should make the municipalities and regencies better able to concentrate on empowerment of local economic power so that the direct impact of economic growth, in addition to the increase in local revenue is also felt directly by the community. One way to grow the regional economy is to improve tourism governance (Koster, 2008); (Archabald \& Naughton-Treves, 2001); (Walpole \& Goodwin, 2000); (Blom, 2000); (Spenceley et al., 2019).

Generally, there are 7 sectors that must be developed in tourism: accommodation, adventure and recreation, attractions, events and conference, food and beverage, tourism service, and travel trade. Accommodation is a business that provides specialty services, it includes hotels, villa, cottage, camping, caravan stop, and other accommodation that are used for tourism purposes. The development of accommodation in West Sumatra in recent 
years has increased because the local government makes efforts to increase tourism. Developments can be seen from the increase in the number of accommodations that occur every year in the form of hotels and other accommodations.

\section{Literature Review}

Original Local Government Revenue (OLGR) is revenue that is withheld based on local regulations under the legislation to finance their activities. OLGR consists of 3 main aspects, including local taxes, retributions, and income of regional government corporate and management of separated regional government wealth. The relationship between the tourism industry and regional revenue is connected through the regional revenue channel and tax revenue sharing. The tourism sector can be a linkage for other product and service subsectors in increasing Gross Regional Domestic Revenue (GRDP) and local revenue itself.

Previous research by (Parida et al., 2017); (Sheng, 2017) stated that domestic visitors and foreign visitors can improve the local economy through revenue receipts from tourism. Domestic and foreign visitors are usually attracted to tourist objects, so the increase in the number of admission tickets will increase OLGR. Previous studies by (Nicely \& Palakurthi, 2012); (Wall \& Zhao, 2017) stated local revenue will increase due to visitor average daily spend. These expenses include consumption, accommodation, transportation, and telecommunication costs The higher the number of tourists, the higher the potential for tourists to extend their stay.

Previous studies by (Botti et al., 2018); (González et al., 2019) and (Santos et al., 2020) showed tourist destination increase local revenue. Regions that have high tourist destinations tend to have high local income potential. Every tourist destinations has something that can attract tourists. Objects can offer shows, natural beauty, shopping for souvenirs or culinary tours. In terms of culinary, for example, tourists tend to adapt to local food change their appetite (Santos et al., 2020). Local cultural performances are attractive to foreign tourists and are able to improve the regional economy (Rahmanita, 2019). Regions that have high tourist destinations have the potential to get higher local income.

During the tour, visitors tend to change their appetite and adapt to the culinary offered by the local (Santos et al., 2020); (Kunasegaran et al., 2019); (Björk \& Kauppinen-Räisänen, 2016); (Kauppinen - Räisänen et al., 2013). Eating local food contributes significantly to their overall tourism experience (Santos et al., 2020) The higher the number of visitors who change their appetite to local food, the restaurant tax revenue will increase along with food sales. Restaurant tax revenue will potentially increase OLGR (Nasir et al., 2017); (Sulastri \& Nugraha, 2019); (Puspita \& Wicaksono, 2019) and (Pratamawaty et al., 2019).

Previous studies by (Sheng, 2017); (Afonso, 2015); (Bartle et al., 2003); (González et al., 2019); (Santos et al., 2020); (Bartle et al., 2003) showed hotel tax increase own-source revenue. In local tax revenue, hotel tax plays an important role because it is the highest contributor in several municipalities and regencies in West Sumatra. Although there are still many phenomena due to the constraints of the tax collection system that is applied to hotel taxes, considering the self-assessment system that requires honesty of the taxpayer itself. As a result, several regencies have not succeeded in exceeding the tax targets set. However, this indicates that the West Sumatra tourism sector has a positive influence on the development of West Sumatra in the future.

The theoretical framework was determined by reviewing some previous literature. According to previous research, we build a research model for the number of visitors and OLGR by using the model (Parida et al., 2017); (Sheng, 2017); (Nicely \& Palakurthi, 2012) and (Wall \& Zhao, 2017). Model for tourist destination and OLGR from (Botti et al., 2018; González et al., 2019; Santos et al., 2020) Model for hotel room tax and OLGR by (Bonham \& Gangnes, 1996); (Mak, 1988); (Mazerov \& Expedia, 2011); (Gooroochurn \& Sinclair, 2005); (Sheng, 2017); (Afonso, 2015); (Bartle et al., 2003); (González et al., 2019); (Santos et al., 2020) and (Bartle et al., 2003). Model for restaurant tax and OLGR from (Nasir et al., 2017); (Sulastri \& Nugraha, 2019); (Puspita \& Wicaksono, 2019) and (Pratamawaty et al., 2019). Model for room tax hotel, number of accommodations, and OLGR from (Litvin et al., 2006);(Bird, 1992). Based on the theory and previous study presented above, the following conceptual model is presented in Figure 1. 


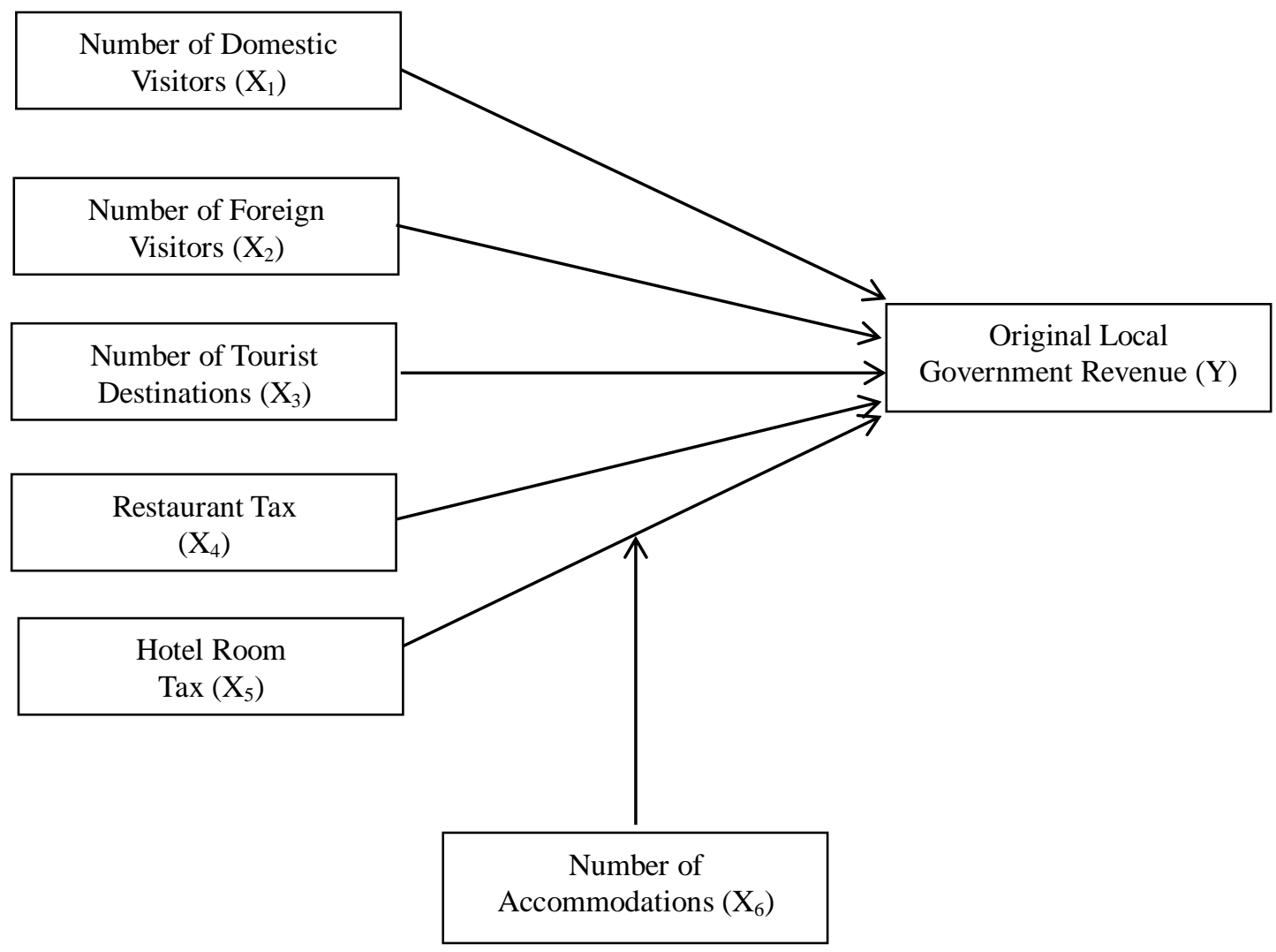

Figure 1. Conceptual Models

The conceptual model in Figure 1 generates 4 hypotheses that will be tested in the study. Therefore, the hypotheses could be formulated as follows:

$H_{1}$ : The number of domestic visitors has a positive and significant effect on OLGR

$\mathrm{H}_{2}$ : The number of foreign visitors has a positive and significant effect on OLGR

$H_{3}$ : The number of tourist destinations has a positive and significant effect on OLGR

$H_{4}$ : Restaurant tax has a positive and significant effect on OLGR

$H_{5}$ : Hotel room tax has a positive and significant effect on OLGR

$H_{6}$ : Number of accommodations as a moderating variable for relationship hotel room tax and OLGR

\section{Methods}

The research approach used is the causality approach. Causal research is research that has the main goal of proving a causal relationship or relationship affecting the variables studied. The research data used are secondary data related to the studied variables obtained from the Central Statistics Agency (BPS) and the Department of tourism during 2014-2019. The objects of this research are regencies and municipalities located in West Sumatra. The total population in this study was 19 , which consisted of 12 regencies and 7 municipalities. The sampling technique is using purposive sampling, where the selected sample is representing West Sumatra tourism according to the Department of Tourism. The samples are Padang city, Bukittinggi city, Payakumbuh city, South Pesisir regency, and Mentawai Islands regency. Sample selection can be seen in Table 1 below.

Data analysis methods consist of descriptive analysis, determination of estimation models, classic assumption test (normality test, heteroskedasticity test, multicollinearity test, and autocorrelation test). Moderated regression analysis by using EViews program. To test the hypotheses, the F-test and the t-test were performed. 
Table 1. Sample selection

\begin{tabular}{lc}
\hline \multicolumn{1}{c}{ Criteria } & Total \\
\hline Regencies and Municipalities in West Sumatera & 19 \\
Regencies and Municipalities that do not yet represent & 14 \\
tourism according to the Tourism Office & \\
Total Sample & 5 \\
\hline
\end{tabular}

Moderated regression analysis equation model is

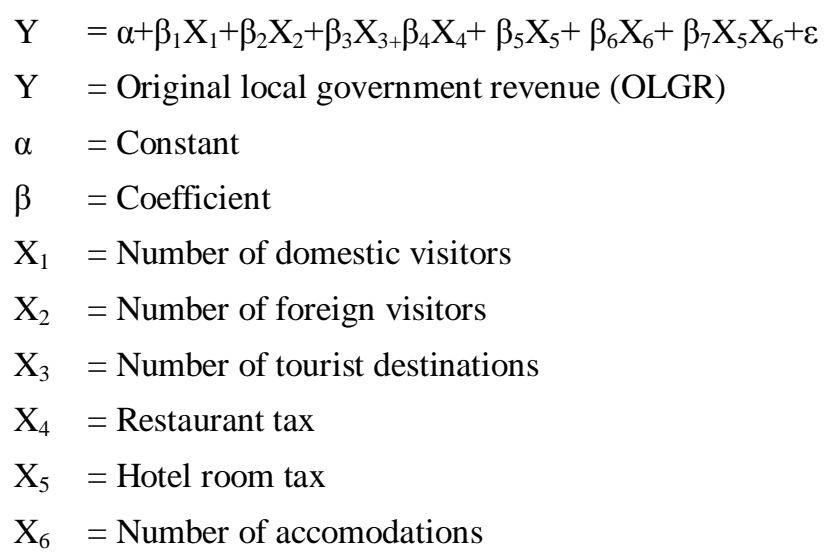

\section{Result and Discussion}

Descriptive statistics are shown in table 2. Mean value of Domestic Visitor $\left(X_{1}\right)$ is 1,286,396 for $2014-2019$. The minimum value of Domestic Visitor $\left(\mathrm{X}_{1}\right)$ is 11,236 visitors that occurred in Mentawai Island during the 2016 period, and the maximum value is 5,384,236 visitors occurred in Padang city during 2019 period. The mean value of Foreign Visitor $\left(\mathrm{X}_{2}\right)$ is 979,953 for 2014-2019. The minimum value of Foreign Visitor $\left(\mathrm{X}_{2}\right)$ is 192 visitors that occurred in Payakumbuh city during 2018 period, and the maximum value is 1,012,820 visitors occurred in Bukittinggi city during 2019 period. The mean value of Tourist Destination $\left(X_{3}\right)$ is 133 tourist objects for 2014-2019. The minimum value of Tourist Destination $\left(\mathrm{X}_{3}\right)$ is 23 tourist objects in Payakumbuh city during 2015 period, and the maximum value is 388 tourist objects in Mentawai Island regency during 2019 period. The mean value of Restaurant Tax $\left(\mathrm{X}_{4}\right)$ is IDR $11,581,488,878.40$ for 2014 - 2019. The minimum value of Restaurant Tax $\left(\mathrm{X}_{4}\right)$ is IDR 1,291,958,000 occurred in South Pesisir regency during 2014 period, and the maximum value is IDR 51,140,836,590 occurred in Padang city during 2019 period. The mean value of Hotel Room Tax $\left(\mathrm{X}_{5}\right)$ is IDR 7,010,656,846.13 for $2014-2019$. The minimum value of Hotel Room Tax $\left(\mathrm{X}_{5}\right)$ is IDR 16,523,418 occurred in Payakumbuh city during 2014 period, and the maximum value is IDR 41,246,273,620 occurred in Padang during 2019 period. The mean value of Number of Accommodations $\left(\mathrm{X}_{6}\right)$ is 51 for $2014-2019$. The minimum value of Number of Accommodations $\left(\mathrm{X}_{6}\right)$ is 10 in Payakumbuh city during 2014 period, and the maximum value is 128 in Padang city during 2018 period.

Determination of estimation models (Chow test, Hausman test, and Lagrange multiplier test), classic assumption tests (normality test, heteroskedasticity test, multicollinearity test, and autocorrelation test) were performed. Chow test is shown in table 3 and the Hausman Test is shown in table 4.

Table 2. Descriptive statistic

\begin{tabular}{llrrrr}
\hline \multicolumn{1}{c}{ Variable } & N & Minimum & Maximum & Mean & Std. Deviation \\
Domestic_Visitor & 30 & 11236 & 5384236 & 1286396 & 1711244.53 \\
Foreign_Visitor & 30 & 192 & 1012820 & 979953 & 2618569.47 \\
Tourist_Destination & 30 & 23 & 388 & 133 & 126.55 \\
Restaurant_Tax & 30 & 1291958000 & 51140836590 & 11581488878.40 & 12520165378.53 \\
Hotel_Room_Tax & 30 & 16523418 & 41246273620 & 7010656846.13 & 10935013246.35
\end{tabular}




$\begin{array}{lrrrrr}\text { Accomodations } & 30 & 10 & 128 & 51 & 37.67 \\ \text { OLGR } & 30 & 36444071405 & 547764962653 & 164051335638.03 & 151906986593.69 \\ \text { Valid N (listwise) } & 30 & & & & \end{array}$

Data processed by author

Table 3. Chow Test result

\begin{tabular}{lccc}
\hline \multicolumn{1}{c}{ Effects Test } & Statistic & d.f. & Prob. \\
\hline Cross-section F & 2.370565 & $(4,18)$ & 0.0911 \\
Cross-section Chi-square & 12.695068 & 4 & 0.0129 \\
\hline
\end{tabular}

Data processed by author

Table 4. Hausman Test result

\begin{tabular}{lccc}
\hline Test Summary & Chi-Sq. Statistic & Chi-Sq. d.f. & Prob. \\
\hline Cross-section random & 10.457554 & 4 & 0.0151 \\
\hline
\end{tabular}

Data processed by author

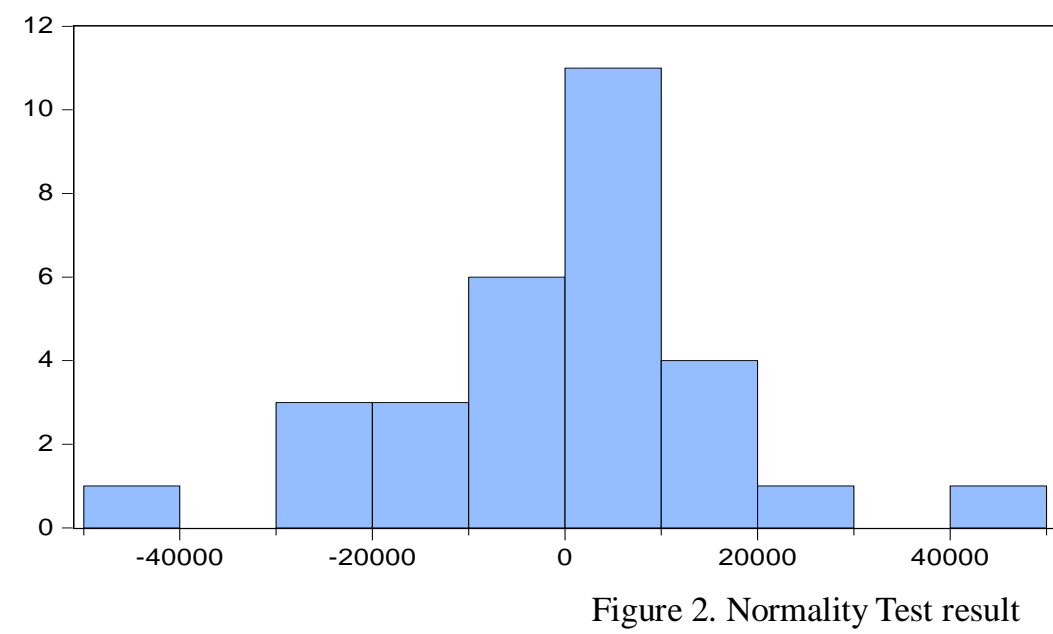

\begin{tabular}{|lr|}
\hline \multicolumn{2}{|l|}{ Series: Standardized Residuals } \\
Sample 2014 2019 \\
\multicolumn{2}{|l}{ Observations 30} \\
Mean & $-9.70 \mathrm{e}-13$ \\
Median & 1714.902 \\
Maximum & 43833.99 \\
Minimum & -43286.66 \\
Std. Dev. & 16713.46 \\
Skewness & -0.186506 \\
Kurtosis & 4.026492 \\
& \\
Jarque-Bera & 1.491029 \\
Probability & 0.474490 \\
\hline
\end{tabular}

Data processed by author

Based on Chow test in Table 3, prob. value of Cross-section Chi-Square is $0.0129<0.005$, which means that fixed effect is better than common effect to estimate the model. The next step is Hausman test. The result is shown in Table 4 above.

Based on Hausman test in Table 4 above, prob. value cross-section random is 0.0151 , which means fixed effect is better than random effect to estimate the model. Based on the output of the Chow test and the Hausman test, the best model for estimating is fixed effect. This model does not require the Lagrange Multiplier test because the results of the chow test and the $f$ test have shown that the fixed effect model is the best estimate.

In classical assumption test, normality test use Jarque-Berra test. The result are shown in Figure 2 above. Based on normality test result, Jarque-Berra prob. is $0.474490>0.05$, which means the data distribution is normal. The second classic assumption test, heteroskedasticity test.

The second classical assumption test, heteroskedasticity test use Glejser test. The result is shown in Table 5 below. The results of the significance of each independent variable $>0.05$. From this result, it can be concluded that there are no symptoms of heteroscedasticity in the data. 
Table 5. Heteroskedasticity Test result

\begin{tabular}{lcc}
\hline \multicolumn{1}{c}{ Variable } & t & Sig \\
\hline Domestic_Visitor & 1.427 & .160 \\
Foreign_Visitor & -1.136 & .268 \\
Tourist_Destination & -.001 & .999 \\
Restaurant_Tax & 1.276 & .208 \\
Hotel_Room_Tax & -.537 & .597 \\
Accomodations & -.819 & .417 \\
Hotel_Room*Tax_Accomodations & .522 & .607 \\
\hline
\end{tabular}

Data processed by author

The result of multicollinearity test is shown in table 6 below. The Uncentered Variance Inflation Factor (VIF) value of each variable $<10$. From this result it can be concluded there are no symptoms of multicollinearity in the data.

Table 6. Multicollinearity Test result

\begin{tabular}{lc}
\hline \multicolumn{1}{c}{ Variable } & Uncentered VIF \\
\hline Domestic_Visitor & 3.22578 \\
Foreign_Visitor & 7.45234 \\
Tourist_Destination & 4.03621 \\
Restaurant_Tax & 8.21330 \\
Hotel_Room_Tax & 9.25589 \\
Accomodations & 4.25563 \\
Hotel_Room*Tax_Accomodations & 3.02582 \\
\hline
\end{tabular}

Data processed by author

Next step is autocorrelation test, the result is shown in table 7 below. The value of Durbin - Watson is 1.852250 . DW > DU $(1.902>1.80817)$, and $(4-D W)>$ DU, $(4-1.902)>1.852250$. From this result it can be concluded there are no symptoms of autocorrelation.

Table 7. Autocorrelation Test result

Mean dependent var

S.D. dependent var

Akaike info criterion

Schwarz criterion

Hannan-Quinn criter.

Durbin-Watson stat

Data processed by author

\section{3}

151907.0

23.05191

23.61239

23.23122

1.852250

Moderated regression analysis was performed to determine whether the relationship between two variables depends on (is moderated by) the value of a third variable. The coefficient of determination test, F-test, and t-test using fixed effect estimation are shown in Table 8. 
Table 8. Coefficient of determination Test, F-test and R-test result

\begin{tabular}{|c|c|c|c|c|}
\hline \multicolumn{2}{|c|}{ Variable } & Coefficient & t-Statistic & Prob. \\
\hline \multicolumn{2}{|c|}{ Domestic_Visitor } & 7.570520 & 4.505251 & $0.0023^{*}$ \\
\hline \multicolumn{2}{|c|}{ Foreign_Visitor } & 1.964661 & 1.986828 & $0.0962 * *$ \\
\hline \multicolumn{2}{|c|}{ Tourist_Destination } & 2.159050 & 1.997541 & $0.0956^{* *}$ \\
\hline \multicolumn{2}{|c|}{ Restaurant_Tax } & 9.351952 & 4.505543 & $0.0007^{*}$ \\
\hline \multicolumn{2}{|c|}{ Hotel_Room_Tax } & 4.776480 & 2.514581 & $0.0365^{*}$ \\
\hline \multicolumn{2}{|c|}{ Accomodations } & 1396.411 & 2.074312 & $0.0461 *$ \\
\hline \multicolumn{2}{|c|}{ Hotel_room_tax*Accomodations } & 6.055979 & 3.019810 & $0.0074 *$ \\
\hline R-squared & 0.987895 & \multicolumn{2}{|c|}{ Mean dependent var } & 164051.3 \\
\hline Adjusted R-squared & 0.980497 & \multicolumn{2}{|c|}{ S.D. dependent var } & 151907.0 \\
\hline S.E. of regression & 21214.32 & \multicolumn{2}{|c|}{ Akaike info criterion } & 23.05191 \\
\hline Sum squared resid & $8.10 \mathrm{E}+09$ & \multicolumn{2}{|c|}{ Schwarz criterion } & 23.61239 \\
\hline Log likelihood & -333.7787 & \multicolumn{2}{|c|}{ Hannan-Quinn criter. } & 23.23122 \\
\hline F-statistic & 133.5406 & \multirow{2}{*}{\multicolumn{2}{|c|}{ Durbin-Watson stat }} & 1.852250 \\
\hline Prob(F-statistic) & 0.000000 & & & \\
\hline
\end{tabular}

$*$ Significant at 0.05 level, $\mathrm{t}$-table $=2.0687$

** Significant at 0.1 level, t-table $=1.7139$

Data processed by author

The coefficient of determination test is presented in table 8 above. The value of Adjusted R Squared is 0.980497 or 98.0497\%. That means the contribution of independent variables and moderating variables (Domestic Visitor $\left(\mathrm{X}_{1}\right)$, Foreign Visitor $\left(\mathrm{X}_{2}\right)$, Tourist Destination $\left(\mathrm{X}_{3}\right)$, Restaurant Tax $\left(\mathrm{X}_{4}\right)$, Hotel Room Tax $\left(\mathrm{X}_{5}\right)$ and Accommodations $\left(\mathrm{X}_{6}\right)$ on independent variable OLGR (Y) is $98.0497 \%$. The rest is influenced by other variables outside this research.

Based on the output in Table 8 above. $F$ test is statistically significant at prob. is $0.000<0.05$. Value of $F$ statistic $>F$ table $(133.5406>2.72)$. Simultaneously, Domestic Visitor $\left(\mathrm{X}_{1}\right)$, Foreign Visitor $\left(\mathrm{X}_{2}\right)$, Tourist Destination $\left(\mathrm{X}_{3}\right)$, Restaurant Tax $\left(\mathrm{X}_{4}\right)$, Hotel Room Tax $\left(\mathrm{X}_{5}\right)$, and Accommodations $\left(\mathrm{X}_{6}\right)$ on OLGR (Y).

To test the effect of the independent variable on the dependent variable partially, t-test was performed. The result is shown in Table 8 above. For H1 test, Domestic Visitor $\left(\mathrm{X}_{1}\right)$ prob. is $0.0023<0.05$, t-statistic > t-table $(4.505251>$ 2.0687). That means Domestic Visitor $\left(X_{1}\right)$ has a positive and significant effect on OLGR. H1 is accepted. This result is in line with previous studies by (Nicely \& Palakurthi, 2012; Parida et al., 2017; Sheng, 2017; Wall \& Zhao, 2017). An increase in the number of domestic visitors will increase local income. Tourists will purchase tickets to enter tourism objects, where the increase in ticket sales will increase OLGR. In this case, ticket sales for tourist attractions are a component of retribution that can increase OLGR Other purchases related to consumption during the trip will increase OLGR through restaurant tax revenue. Transportation costs paid by visitors will also increase OLGR because visitors need transportation from one tourist attraction to another. The high number of visitors will increase sales in shopping center-based attractions.

For $\mathrm{H}_{2}$ test, Foreign Visitor $\left(\mathrm{X}_{2}\right)$ prob. is $0.0962<0.10$, t-statistic $>\mathrm{t}$-table $(2.164661>1.7139)$. That means Domestic Visitor $\left(\mathrm{X}_{1}\right)$ has a positive and significant effect on OLGR. $\mathrm{H}_{2}$ is accepted. This research in line with previous studies by (Nicely \& Palakurthi, 2012; Parida et al., 2017; Sheng, 2017; Wall \& Zhao, 2017). The explanation about domestic visitors also applies to foreign visitors. Although the number of foreign visitors is not able to equal the number of domestic visitors. In this case, the foreign visitor variable should not be ignored in increasing OLGR. They tend to like new things to add to tourism experience. Their presence tends to increase restaurant visitors and hotel occupancy rates. Things that according to residents or domestic tourists are common, on the contrary for foreign tourists it is an experience that has high value. Even in the literature that has been described, foreign tourists can change consumption tastes and adjust to local tastes. This will affect OLGR through local restaurant tax revenues. 
For $\mathrm{H}_{3}$ test, Tourist Destination $\left(\mathrm{X}_{3}\right)$ prob. is $0.0956<0.10$, $\mathrm{t}$-statistic $>\mathrm{t}$-table $(1.997541>1.7139)$. That means Domestic Visitor $\left(\mathrm{X}_{3}\right)$ has a positive and significant effect on OLGR. $\mathrm{H}_{3}$ is accepted. This research in line with previous studies by (Botti et al., 2018); (González et al., 2019); (Santos et al., 2020); (Rahmanita, 2019). Tourist destinations can be based on natural tourism, marine tourism, historical tourism, cultural tourism, and culinary tourism. The more the number of tourist destinations and the more types of tourism offered to visitors, the visitors can have which alternative tours they prefer. Different types of tourist destinations will result in differences in tourist expenditure (Pratamawaty et al., 2019). OLGR will increase as the number of tourist destinations increases. This is due to the increasing number of tourist destinations, the higher the potential for tourist expenditure. Visitors who prefer culinary, they will be willing to pay more for culinary tours. Visitors who like nature tourism, they will stay longer and visit one place to another.

For $\mathrm{H}_{4}$ test, Restaurant Tax $\left(\mathrm{X}_{4}\right)$ prob. is $0.0007<0.05$, t-statistic $>\mathrm{t}$-table $(4.505543>1.7139)$. That means Restaurant tax $\left(\mathrm{X}_{4}\right)$ has a positive and significant effect on OLGR. $\mathrm{H}_{4}$ is accepted. This research in line with previous studies by (Björk \& Kauppinen-Räisänen, 2016; Kauppinen-Räisänen et al., 2013; Kunasegaran et al., 2019; Nasir et al., 2017; Pratamawaty et al., 2019; Puspita \& Wicaksono, 2019; Santos et al., 2020; Sulastri \& Nugraha, 2019). Eating local food contributes significantly to its overall tourism experience. Food curiosity makes visitors willing to spend more money to try something new that will add to their experience. The higher the number of visitors who change their appetite to local food, the restaurant tax revenue will increase along with food sales. Restaurant tax revenue will potentially increase OLGR. Several previous studies have also shown that local food will be preferred by visitors rather than serving the original food of the visitor.

For $\mathrm{H}_{5}$ test, Hotel Room Tax $\left(\mathrm{X}_{5}\right)$ prob. is $0.0365<0.05$, $\mathrm{t}$-statistic $>\mathrm{t}$-table $(2.514581>1.7139)$. That means Hotel Room Tax $\left(\mathrm{X}_{5}\right)$ has a positive and significant effect on OLGR. $\mathrm{H}_{5}$ is accepted. This research are line with previous studies by (Bonham \& Gangnes, 1996); (Mak, 1988); (Mazerov \& Expedia, 2011); (Gooroochurn \& Sinclair, 2005); (Febriantoko \& Mayasari, 2018); (Sheng, 2017); (Afonso, 2015); (Bartle et al., 2003); (González et al., 2019) and (Bartle et al., 2003). Hotel room tax has an important role in OLGR's growth contribution, especially in areas with well-known tourism. The number of visits that increase at the hotel both local and foreign tourists, or the duration of stay, will make tax revenue increase which will also increase OLGR. The government needs to conduct oversight of accommodations so that compliance and honesty in tax revenue increase.

For $\mathrm{H}_{6}$. Hotel room tax*number of accommodations prob. is $0.0074<0.05$, $\mathrm{t}$-statistic $>\mathrm{t}$-table $(3.019810>1.7139)$. the number of accommodations shows evidence as a moderating variable for the relationship of hotel tax with original local government revenue. $\mathrm{H}_{6}$ is accepted. This research in line with previous studies by (Litvin et al., 2006); (Bird, 1992); (Dogru et al., 2020). In this study, we have found evidence of the number of accommodations that have a significant effect on OLGR. The increasing number of accommodations will increase tax revenue and have a positive impact on the increase in OLGR. Furthermore, number of hotels increases employment in both the overall economy and the tourism, leisure, and hospitality industries. Medium hotels make the highest contribution to employment in the overall economy. Small hotels make the biggest contribution to employment in the overall tourism, leisure, and hospitality industries.

\section{Conclusion}

This research aims to discover 1) The effect of number of domestic visitors on Original Local Government Revenue (OLGR) 2) The effect of number of foreign visitors on OLGR 3) The effect of number of tourist destinations on OLGR 4) The effect of restaurant tax on OLGR 5) The effect of hotel room tax on OLGR 6) Number of accommodations as a moderating variable for relationship hotel room tax and OLGR. The results show 1) The number of domestic visitors has a positive and significant effect on OLGR 2) The number of foreign visitors has a positive and significant effect on OLGR 3) The number of tourist destinations has a positive and significant effect on OLGR 4) Restaurant tax has a positive and significant effect on OLGR 5) Hotel room tax has a positive and significant effect on OLGR 6) Number of accommodations show evidence as a moderating variable for relationship hotel room tax and OLGR.

Local government and stakeholders need to improve all aspects of this research variable to maximize OLGR. For further researchers, it is recommended to add research variables related to tourism development. Researchers can expand the object of research and increase the number of samples using more specific criteria.

\section{Acknowledgment}

All authors would like to thank Universitas Putra Indonesia YPTK and Yayasan Perguruan Tinggi Komputer for financial support. Any remaining errors are own. 


\section{References}

Afonso, W. B. (2015). Lost and found tax dollars: The impact of local option sales taxes on property taxes and own source revenue. Journal of Public Budgeting, Accounting \& Financial Management, 27(3), 318-351. https://doi.org/10.1108/JPBAFM-27-03-2015-B002

Archabald, K., \& Naughton-Treves, L. (2001). Tourism revenue-sharing around national parks in Western Uganda: early efforts to identify and reward local communities. Environmental Conservation, 135-149.

Bartle, J. R., Ebdon, C., \& Krane, D. (2003). Beyond the property tax: local government revenue diversification. Journal of Public Budgeting, Accounting \& Financial Management, 15(4), 622-648. https://doi.org/10.1108/JPBAFM-15-04-2003-B006

Bird, R. M. (1992). Taxing tourism in developing countries. World Development, 20(8), 1145-1158.

Björk, P., \& Kauppinen-Räisänen, H. (2016). Local food: a source for destination attraction. International Journal of Contemporary Hospitality Management.

Blom, A. (2000). The monetary impact of tourism on protected area management and the local economy in Dzanga-Sangha (Central African Republic). Journal of Sustainable Tourism, 8(3), 175-189.

Bonham, C. S., \& Gangnes, B. (1996). Intervention analysis with cointegrated time series: the case of the Hawaii hotel room tax. Applied Economics, 28(10), 1281-1293.

Botti, A., Monda, A., \& Vesci, M. (2018). Organizing Festivals, Events and Activities for Destination Marketing. In M. A. Camilleri (Ed.), Tourism Planning and Destination Marketing (pp. 203-219). Emerald Publishing Limited. https://doi.org/10.1108/978-1-78756-291-220181010

Condro, G. D., Rizky, S. B., \& Maqnus, S. A. (2019). The paradox of political dynasties of regeneration type and poverty in regional autonomy era. International Journal of Ethics and Systems, 35(2), 179-194. https://doi.org/10.1108/IJOES-05-2018-0069

Dogru, T., McGinley, S., \& Kim, W. G. (2020). The effect of hotel investments on employment in the tourism, leisure and hospitality industries. International Journal of Contemporary Hospitality Management.

Febriantoko, J., \& Mayasari, R. (2018). 17 Years Of Establishment Of Pagaralam As A Tourism City: How Is The Tourism Sector'S Ability To Increase Original Local Government Revenue?. Int. J. Sci. Eng. Sci, 2(9), 61-64.

Feltenstein, A., \& Iwata, S. (2005). Decentralization and macroeconomic performance in China: regional autonomy has its costs. Journal of Development Economics, 76(2), 481-501.

González, A. F., Curtis, C., Washburn, I. J., \& Shirsat, A. R. (2019). Factors in tourists' food decision processes: a US-based case study. Journal of Tourism Analysis: Revista de Análisis Turístico.

Gooroochurn, N., \& Sinclair, M. T. (2005). Economics of tourism taxation: Evidence from Mauritius. Annals of Tourism Research, 32(2), 478-498.

Kauppinen-Räisänen, H., Gummerus, J., \& Lehtola, K. (2013). Remembered eating experiences described by the self, place, food, context and time. British Food Journal.

Koster, R. L. (2008). Mural-based tourism as a strategy for rural community economic development. In A. G. Woodside (Ed.), Advances in Culture, Tourism and Hospitality Research (Vol. 2, pp. 153-292). Emerald Group Publishing Limited. https://doi.org/10.1016/S1871-3173(08)02004-1

Kunasegaran, M., Rasoolimanesh, S. M., \& Khan, S. K. (2019). Experiences of international tourists with healthy signature foods: a case study in Malacca. British Food Journal.

Litvin, S. W., Crotts, J. C., Blackwell, C., \& Styles, A. K. (2006). Expenditures of accommodations tax revenue: A South Carolina study. Journal of Travel Research, 45(2), 150-157.

Mak, J. (1988). Taxing hotel room rentals in the US. Journal of Travel Research, 27(1), 10-15.

Mazerov, M., \& Expedia, O. (2011). State and Local Governments Should Close Online Hotel Tax Loophole and Collect Taxes Owed. Center on Budget and Policy Priorities.

Nasir, A., Basri, Y. M., \& Kamaliah, K. (2017). Effectiveness of Potential Tax Region as the Real Local Revenue Sources in Riau Coastal Area. Annual Conference on Economics, Business, Accounting and Social Sciences (ACEBASS) 2017.

Nicely, A., \& Palakurthi, R. (2012). Navigating through tourism options: an island perspective. International Journal 
of Culture, Tourism and Hospitality Research, 6(2), 133-144. https://doi.org/10.1108/17506181211233063

Parida, Y., Bhardwaj, P., \& Chowdhury, J. R. (2017). Determinants of tourism in Indian states: an empirical analysis. Tourism Review, 72(3), 330-343. https://doi.org/10.1108/TR-11-2016-0047

Pratamawaty, B. B., Cahyadini, A., Julianja, S., \& Veronica, G. S. (2019). Policy Communication Strategy of Restaurant Tax to Increase Bandung's Own-Source Revenue. IOP Conference Series: Earth and Environmental Science, 248(1), 12068.

Puspita, Y., \& Wicaksono, G. (2019). The Analysis Of Potential Restaurant Tax Revenue In Banyuwangi Regency. The International Seminar Series on Regional Dynamics, 1(1).

Rahmanita, M. (2019). Assessing Tourist Spending at an Attraction. In Delivering Tourism Intelligence. Emerald Publishing Limited.

Santos, J. A. C., Santos, M. C., Pereira, L. N., Richards, G., \& Caiado, L. (2020). Local food and changes in tourist eating habits in a sun-and-sea destination: a segmentation approach. International Journal of Contemporary Hospitality Management.

Sheng, L. (2017). Factors determining the success or failure of a tourism tax: a theoretical model. Tourism Review, 72(3), 274-287. https://doi.org/10.1108/TR-02-2017-0030

Spenceley, A., Snyman, S., \& Rylance, A. (2019). Revenue sharing from tourism in terrestrial African protected areas. Journal of Sustainable Tourism, 27(6), 720-734.

Sulastri, L., \& Nugraha, P. (2019). Supervision of Hotel and Restaurant Tax Learning to Improve Regional Original Income (PAD) Sumedang District. Journal of Economic Empowerment Strategy (JEES), 2(1), 13-23.

Wall, G., \& Zhao, N. R. (2017). China's red tourism: communist heritage, politics and identity in a party-state. International Journal of Tourism Cities, 3(3), 305-320. https://doi.org/10.1108/IJTC-03-2017-0017

Walpole, M. J., \& Goodwin, H. J. (2000). Local economic impacts of dragon tourism in Indonesia. Annals of Tourism Research, 27(3), 559-576.

\section{Copyrights}

Copyright for this article is retained by the author(s), with first publication rights granted to the journal.

This is an open-access article distributed under the terms and conditions of the Creative Commons Attribution license (http://creativecommons.org/licenses/by/4.0/). 